\title{
DARBO APLINKOS VEIKSNIŲ ITTAKA SLAUGYTOJŲ SVEIKATAI
}

\author{
Gintarė Aukštikalnytė, Danguolė Drungilienè, \\ Viljaras Reigas, Gintautas Minelga \\ Klaipédos universitetas
}

\section{SANTRAUKA}

Tyrimo pagrindimas. Sveikatos priežiūros specialistų darbo aplinka yra svarbus veiksnys, kuris turi įtakos dirbančiujų gyvenimo kokybei ir sveikatai. Darbe vyraujant psichosocialiniams rizikos veiksniams, tokiems kaip stresas, ilgos darbo valandos, dideli reikalavimai, susidūrimas su pacientu smurtu bei mirtimi, pamaininis darbas ir pan., sutrinka darbo ir poilsio režimas, darbuotojams sukeliamas stresas, pervargimas ir kt. Ne visi slaugytojai geba atlaikyti nuolat patiriamą darbo įtampą, todèl padidèja nepageidaujamų sveikatos problemų tikimybè.

Tikslas. Išanalizuoti darbo aplinkos veiksnių įtaką slaugytojų sveikatai.

Metodai. Anketinès apklausos būdu apklausti 121 slaugytojas, dirbančias ligoninėse. Apklausai atlikti naudojamos darbo patirties vertinimo (WEMS) ir salutogeninių sveikatos indikatorių skalès (SHIS).

Rezultatai. Slaugytojų sveikata vertinta „Salutogeninių sveikatos indikatorių skale“. Bendrojo sveikatos rodiklio vidurkị bendroje tiriamujų grupeje sudare 60,96 balo, tarpasmeninių sveikatos indikatorių grupése $-59,81$ balo ir interaktyvių - 62,58 balo. Geriausiai vertintas bendravimas su kitais žmonėmis ( 4,38 balo), ryžtingumas ( 4,27 balo), emocinės pusiausvyros išlaikymas ( 4,20 balo), o blogiausiai miegas ( 3,74 balo), atsipalaidavimas $(3,82$ balo) ir energingumas ( 3,85 balo). Darbo patyrimo skalèje geriausiai vertintas prieinamumas prie vadovo, vadovo gebėjimas, prireikus priimti sprendimus, blogiausiai - vadovo konsultavimasis su darbo grupe prieš priimant svarbius sprendimus. Darbo pokyčių srities teiginiai buvo vertinami blogiau nei kitų sričių, vyrai žymiai pozityviau vertino pokyčius įstaigoje nei moterys.

Išvados. Teigiama darbo patirtis buvo susijusi su geresniu savo sveikatos ir savijautos vertinimu. Bendrasis sveikatos rodiklis buvo blogesnis tarp tiriamujų su didesniu darbo stažu, jie blogiau vertino tiek tarpasmeninius, tiek interaktyvius sveikatos indikatorius. Jaunesnio amžiaus slaugytojai palankiau vertino pokyčius įstaigoje, o vadovavimo sritị pozityviau vertino slaugytojai, turintys didesnị darbo stažą.

Raktažodžiai: slaugytojai, sveikatos indikatoriai, darbo veiksniai.

\section{IVADAS}

Aplinka, kurioje žmogus praleidžia didžiają dienos dalị yra darbo aplinka, ji turi daug ịtakos sveikatai, todèl moksliniuose tyrimuose darbinei veiklai skiriamas didelis dėmesys. Sveikatos priežiūros specialistų darbo aplinka yra svarbus veiks-

Copyright (C) 2021 Gintarė Aukštikalnytė, Danguolè Drungilienė, Viljaras Reigas, Gintautas Minelga Published by Lithuanian Sports University.

This is an Open Access article distributed under the terms of the Creative Commons Attribution 4.0 International License, which permits unrestricted use, distribution, and reproduction in any medium, provided the original author and source are credited. 
nys turintis tiek teigiamą, tiek neigiamą poveikị dirbančiųjų gyvenimo kokybei ir sveikatai. C. Bergman et al. (2017) nurodo, kad darbo pobūdis sveikatos priežiūros organizacijose apima glaudžius ryšius su pacientais ir atsakomybę už jų sveikatą bei gerovę. Nuolat vykstant sveikatos reformoms, didejja reikalavimai sveikatos priežiūros specialistams. Visuomenè kelia vis didesnius reikalavimus asmeninėms ir profesinèms medikų savybėms (Karpavičiūtè, 2016; Žiedelis, 2020). Slaugytojų darbas sunkus, jiems kasdien tenka artimai bendrauti su sergančiais žmonėmis, sergančiujų šeimos nariais, susidurti su pacientų mirtimi, dažnai patirti nesėkmes. Slaugytojai savo darbe nuolat patiria psichosocialinę riziką, nes ne visada pavyksta laikytis rekomenduojamo darbo ir poilsio režimo, ypač pamaininio darbo metu. K. Dringelytė et al. (2019) pabrèžia, kad pamaininio darbo laiko pokyčiai veikia cirkadinius ritmus, desinchronizuoja organizmo miego ir būdravimo režimą, o dirbantieji naktị miega 2-4 val. trumpiau nei dirbantys dieną. A. Žiedelio (2019) nuomone, slaugytojų darbo aplinka apibrěžiama kaip ypač žalinga jų sveikatai, išskiriami specifiniai slaugytojų rizikos veiksniai: darbo krūvio didèjimas, rizika susidurti su pacientu smurtu, probleminiai santykiai su gydytojais, įstaigos keliami veiksmingumo reikalavimai. M. Martinaitytès tyrime (2018) nurodoma, kad sveikatos priežiūros įstaigų darbe vyrauja psichosocialiniai rizikos veiksniai, tokie kaip stresas, ilgos darbo valandos ir dideli reikalavimai, atlygio už darbą neatitikimas ir daugelis kitų veiksnių, kurie galimai sukelia pervargimą. Stresas yra stiprus veiksnys, kuris gali sukelti pervargimą. Taip pat slaugytojų patiriamas stresas ir nuovargis turi neigiamos įtakos ir pacientų saugumui (Karpavičiūte, 2016). Vis dažniau pasirodo informacijos apie stacionare dirbančių slaugytojų pervargimą, emocinị išsekimą, neprofesionalumą, konfliktus darbo aplinkoje, abejingumą slaugomiems pacientams. Tokie reiškiniai ir atlikti tyrimai rodo sveikatos priežiūros darbuotojų perdegimo sindromą. R. Vimantaitė (2007) nurodo, jog neigiamos visuomenès reakcijos sulaukiama, kai klaidas padaro medicinos darbuotojai. Nors stresas susijęs su darbo aplinka, tačiau jo pasekmès pasireiškia asmeniniu lygiu, nes paliečia dirbančiụjų asmeninị ir socialinị gyvenimą. L. Bratikaitės (2010) atlikti tyrimai rodo, kad darbe patiriamas stresas didina įvairių priklausomybes skatinamujų medžiagų vartojimą. Ne visi slaugytojai geba atlaikyti nuolat patiriamą stresą darbe, todèl padidèja nepageidaujamų sveikatos problemų rizika. Ilgalaikis stresas, nerimas, nekompetetingumo jausmas, paskatinimų ir palaikymo stygius turi ittakos perdegimo sindromo ir depresijos rizikai.

E. Piekutès et al., (2016) nuomone, darbo vietoje visada būtina ieškoti pozityvesnių veiksnių, skatinančių darbuotojų sveikatos stiprinimą arba padedančių išlaikyti esamą sveikatą. Reakcijos ị problemą, jos sprendimą priklauso nuo pačių slaugytojų elgesio, jų asmeninès motyvacijos, nuo požiūrio ir perspektyvos matymo, nuo asmenybès tipo (Vimantaitè, 2005; Polikandrioti, 2009). Kai kurie žmo- 
nès visuomet yra labiau patenkinti savo darbu nei kiti. Pasitenkinimas darbu - tai poreikių patenkinimas per darbą. Jis parodo žmogaus lūkesčių ir gaunamo atlygio atitikimą. Pasitenkinimas darbu yra asmeninè nuostata.

Tyrimo tikslas - išanalizuoti darbo aplinkos veiksnių įtaką slaugytojų sveikatai.

\section{TYRIMO METODAI IR TIRIAMIEJI}

Tyrimo organizavimas ir eiga. Tyrimas atliktas Klaipedos ligoninėse $2020 \mathrm{~m}$. rugsėjo-spalio mèn., gauti leidimai vykdyti tyrimą iš ligoninių vadovų. Leidimą naudoti anketą bei lietuvišką jos variantą suteikè instrumento autoriai. Vykdant tyrimą buvo garantuotas Helsinkio deklaracijos ir etikos principų laikymasis.

Tiriamieji. Anketinès apklausos būdu apklaustas 121 slaugytojas (išdalyti 149 klausimynai, atsako dažnis -81 proc.), dirbantis Klaipèdos ligoninèse. Daugumą (93,4 proc.) tiriamujų sudare moterys, vyrų buvo 6,6 proc. Pagal amžių didžiausią grupę ( 37,2 proc.) sudare $40-49$ metų tiriamieji, 29,8 proc. buvo vyresni nei 49 metų, 22,3 proc. tiriamujų buvo 30-39 metų ir 10,7 proc. - jaunesni nei 30 metų. Pagal darbo krūvị ịstaigoje, kurioje buvo vykdoma apklausa, dauguma (59,5 proc.) tiriamujų dirbo didesniu nei pusès arba vieno etato krūviu, didesniu nei vieno etato krūviu dirbo apie trečdalis (33,9 proc.) tiriamujų, mažu (iki pusès etato) krūviu 6,6 proc. Pagal darbo stažą didžiausią grupę (33,9 proc.) sudarè slaugytojai, išdirbę daugiau nei 20 metų, mažiausią (14,9 proc.) - iki penkerių metų.

Tyrimo metodai. Apklausai naudoti Kristianstad universiteto mokslininkų parengti instrumentai: Darbo patyrimo vertinimo skalè (WEMS) ir Salutogeninių sveikatos indikatorių skale (SHIS). WEMS skalę sudare 32 teiginiai, kurie rodo dirbančiujų reakciją ị šešias darbo organizavimo ir tarpusavio santykių darbe sritis, vertinami Likert'o skale. SHIS skalè, sudaryta iš 12 teiginių, buvo sukurta remiantis holistine sveikatos samprata. Tiriamasis turi balais įvertinti, kiek jis sutinka su kiekvienu teiginiu. Balai yra išdèstyti nuo 1 (visiškai nesutinku) iki 6 (visiškai sutinku). Sveikata vertinama remiantis bendru skalès vidurkiu. Šios skalès teiginiai suskirstyti ị dvi grupes - tarpasmeninius (7 teiginiai) ir interaktyvius (5 teiginiai) sveikatos indikatorius. Darbe tiriamujų sveikata buvo vertinama remiantis bendrais skalès ir atskirais sveikatos indikatorių grupių suminiais standartizuotais balais, didesnis balas rodo geresnį savo sveikatos vertinimą (Bringsén et al., 2009). Visos skalés galëjo igyti reikšmes nuo 0 iki 100 balų.

Apskaičiuoti abiejų klausimynų skalių vidinio suderinamumo (angl. internal consistency) koeficientai, kurie rodo vidinị klausimų homogeniškumą pagal Cronbach'o Alfa koeficiento skaičiavimo metodą. SHIS klausimyno ir jo skalių vidinis patikimumas yra aukštas - Cronbach'o Alfa koeficientai yra didesni nei 
0,7. WEMS klausimyno Cronbach'o Alfa koeficientai taip pat yra didesni nei 0,7. Galima teigti, jog klausimynų vidinis patikimumas yra aukštas.

Statistinè duomenų analizè. Duomenims apdoroti naudota „SPSS 23.0.0“ statistinès analizès paketas. Tikrintas intervalinių kintamųju pasiskirstymas pagal normalujji dėsni, naudojant Shapiro'o-Wilk'o testą bei ịvertinant asimetrijos ir eksceso koeficientų dydžius. Dviejų nepriklausomų grupių požymių vidurkių palyginimui naudotas neporinis Student'o (t) kriterijus, neturintiems - Mann'oWhitney'aus kriterijus (U). Daugiau nei dviejų nepriklausomų grupių požymių, turintiems normaluji pasiskirstymą, palyginimui naudotas One-Way ANOVA (F) metodas, neturintiems - Kruskal'io-Wallis'o $(\chi 2)$ testas. Naudoti statistinių hipotezių reikšmingumo lygmenys: statistiškai reikšmingas, kai $p<0,05$, statistiškai nereikšmingas, kai $\mathrm{p}>0,05$.

\section{REZULTATAI}

Slaugytojų sveikata vertinta Salutogeninių sveikatos indikatorių skale, kurios teiginiai suskirstyti ị tarpasmeninius ir interaktyvius sveikatos indikatorius. Salutogeninių sveikatos indikatorių vertinimų vidurkiai bendroje grupèje - 3,74-4,38 balo (1 pav.).

Geriausiai įvertintas bendravimas su kitais žmonèmis ( 4,38 balo), ryžtingumas (4,27 balo), emocinès pusiausvyros išlaikymas ( 4,20 balo), o blogiausiai - miegas (3,74 balo), atsipalaidavimas (3,82 balo) ir energingumas (3,85 balo).

Bendrojo sveikatos rodiklio vidurkị bendroje tiriamujų grupejje sudare $60,96 \pm 19,25$ balo, tarpasmeninių sveikatos indikatorių grupès $-59,81 \pm 20,16$ balo ir interaktyviu $-62,58 \pm 19,10$ balo.

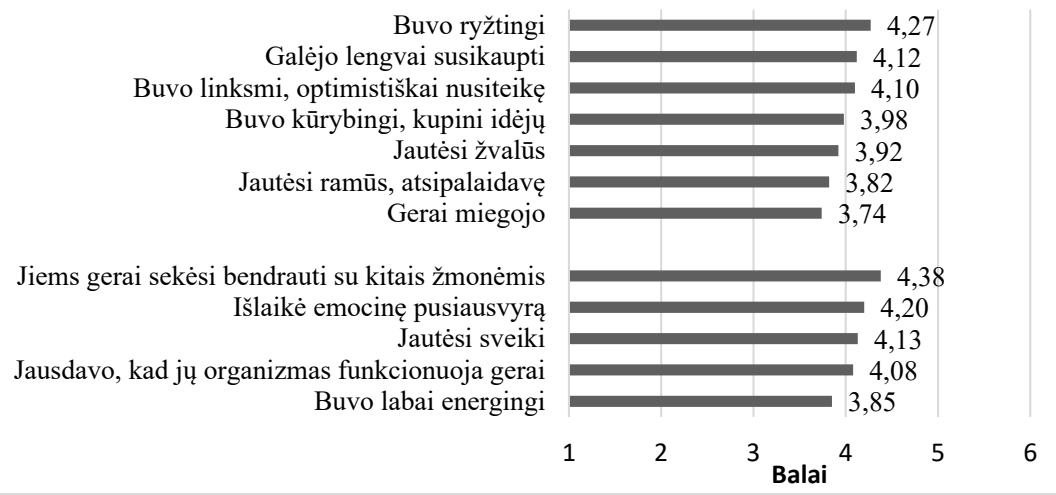

1 pav. Salutogeninių sveikatos indikatorių ịverčiai (balais) bendroje slaugytojų grupẻje 


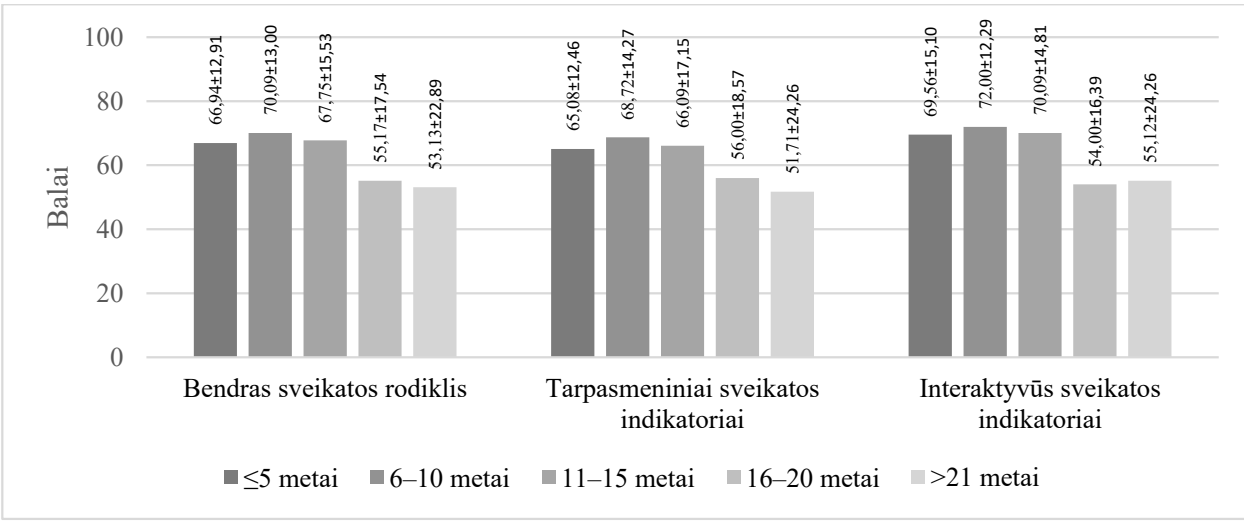

* $\mathrm{p}$ - reikšmingumo lygmuo.

2 pav. Sveikatos vertinimas salutogeniniais sveikatos indikatoriais, priklausomai nuo slaugytojų darbo stažo $(p<0,05)$

Tyrimo rezultatų duomenimis, sveikatos rodiklių vertinimai yra susiję su tiriamujjų darbo stažu - tiriamieji, kurie turèjo didesnị nei 15 metų darbo stažą, statistiškai reikšmingai blogiau vertino tiek tarpasmeninius, tiek interaktyvius sveikatos indikatorius nei turintys mažesnį darbo stažą (2 pav.).

Analizuojant sveikatos rodiklius, priklausomai nuo tiriamujų lyties ir amžiaus, statistiškai reikšmingų skirtumų nenustatyta. Sveikatos rodikliai taip pat statistiškai reikšmingai nesiskyrè, priklausomai nuo tiriamųjų darbo krūvio.

Tyrimo rezultatai parodè, kad ir tarpasmeninių ir interaktyvių sveikatos indikatorių grupès taip pat statistiškai reikšmingai teigiamai susijusios su tomis pačiomis darbo patirties sritimis, kaip ir bendrasis sveikatos rodiklis: su palaikančiais darbo santykiais (atitinkamai $-\mathrm{p}<0,001$ ir $\mathrm{p}=0,002$ ), su laiko patyrimu (atitinkamai $-\mathrm{p}$ $<0,001$ ir $\mathrm{p}<0,001$ ), su vadovavimu (atitinkamai $-\mathrm{p}=0,001$ ir $\mathrm{p}=0,019$ ) ir $\mathrm{su}$ reorganizacija (atitinkamai $-\mathrm{p}=0,010$ ir $\mathrm{p}=0,018$ ) (1 lentelè).

Didesni koreliacijos koeficientai parode, kad tarpasmeniniai sveikatos indikatoriai yra stipriau susiję su palaikančiais darbo santykiais, vadovavimu ir reorganizacija nei interaktyvūs sveikatos indikatoriai.

Tiriamujų darbo patyrimas buvo vertinamas Darbo patyrimo vertinimo skale, kurią sudare šešios darbo organizavimo ir tarpusavio santykių darbe sritys. 


\section{1 lentelè. Darbo patirties sričių koreliaciniai ryšiai su sveikatos, įvertintos salutogeniniais sveikatos indikatoriais, skalėmis}

\begin{tabular}{|c|c|c|c|c|c|c|}
\hline \multirow{3}{*}{ WEMS sritys } & \multicolumn{6}{|c|}{ SHIS skalès } \\
\hline & \multicolumn{2}{|c|}{$\begin{array}{l}\text { Bendrasis } \\
\text { rodiklis }\end{array}$} & \multicolumn{2}{|c|}{$\begin{array}{c}\text { Tarpasmeninès } \\
\text { sveikatos } \\
\text { indikatoriai }\end{array}$} & \multicolumn{2}{|c|}{$\begin{array}{c}\text { Interaktyvūs } \\
\text { sveikatos } \\
\text { indikatoriai }\end{array}$} \\
\hline & $\mathbf{r}^{* *}$ & $\mathbf{p} * * *$ & $\mathbf{r * *}$ & $\mathbf{p}^{* * *}$ & $\mathbf{r * *}$ & $\mathbf{p} * * *$ \\
\hline Palaikantys darbo santykiai* & 0,32 & $<0,001$ & 0,33 & $<0,001$ & 0,28 & 0,002 \\
\hline Individuali patirtis* & 0,13 & 0,157 & 0,13 & 0,171 & 0,13 & 0,160 \\
\hline Atsakomybė $\neq$ & 0,14 & 0,126 & 0,12 & 0,197 & 0,14 & 0,124 \\
\hline Laiko patyrimas $\ddagger$ & 0,35 & $<0,001$ & 0,35 & $<0,001$ & 0,35 & $<0,001$ \\
\hline Vadovavimas $\ddagger$ & 0,26 & 0,004 & 0,29 & 0,001 & 0,21 & 0,019 \\
\hline Reorganizavimas* & 0,23 & 0,011 & 0,23 & 0,010 & 0,21 & 0,018 \\
\hline
\end{tabular}

*_taikytas Pearson'o koreliacijos metodas; $\neq-$ taikytas Spearman'o koreliacijos metodas; **_koreliacijos reikšmé; ***_reikšmingumo lygmuo.

„Palaikančių darbo santykių“ sritị sudare septyni teiginiai, susiję su kolegu palaikymu, pagalbos gavimu iš kolegų, atmosfera darbe, organizuotais darbiniais ippročiais (rutina), atlikto darbo ịvertinimu, savijauta darbe ir darbdavio rūpinimusi darbuotojų sveikata. Šių teiginių vertinimų vidurkiai bendroje tiriamujų grupeje svyravo nuo 3,23 iki 4,97 balo. Geriausiai tiriamieji vertino bendradarbių pagalbą ir palaikymą, blogiausiai - darbdavio rūpinimąsi darbuotojų sveikata.

Individualios patirties sritị sudarè šeši teiginiai, susiję su darbo prasmingumu, atliekamų užduočių ịvairove ir kintamumu, tobulëjimu, atliekamo darbo atitikimu išsilavinimui, pasitenkinimu darbu ir darbo iššūkiu. Šių teiginių vertinimų vidurkiai bendroje tiriamųu grupejje - nuo 3,82 iki 5,14 balo. Geriausiai tiriamieji vertino savo darbo prasmingumą, užduočiu įvairovę, galimybę tobulèti, mažiausiai balų surinko teiginys „Mano darbas man yra didelis iššūkis“.

„Asmeninès atsakomybès" sritį sudarè keturi teiginiai, susiję su galimybe spręsti, kaip darbas turi būti atliekamas, galimybe pasirinkti darbo tempą, spręsti, kas turi būti atliekama, kada turètų būti įvykdomos tam tikros užduotys. Šių teiginių vertinimai buvo panašūs, vidurkis - 4,00-4,44 balo. Geriausiai vertinta galimybe spęsti, kaip turi būti atliekamas darbas.

„Darbo patyrimo“" sritị sudarè trys teiginiai, susiję su laiko pakankamumu užduotims atlikti. Šitų teiginių vertinimų vidurkis $-4,17-4,49$ balo.

„Vadovavimo“" sritị sudare šeši teiginiai, susiję su prieinamumo prie vadovo, vadovo gebèjimu prireikus pačiam priimti sprendimus, pavaldiniu informavimu apie organizacijos tikslus ir vizijas, sąžiningu užduočių paskirstymu, gebejjimu motyvuoti ir sudominti pavaldinius bei konsultavimosi su darbo grupe prieš priimant svarbius sprendimus. Šių teiginių vertinimų vidurkis bendroje tiriamųu 
grupeje - 4,23-4,82 balo. Geriausiai tiriamieji vertino prieinamumą prie vadovo, vadovo gebėjimą, prireikus priimti sprendimus, blogiausiai - vadovo gebejjimą, prireikus priimti svarbius sprendimus.

„Reorganizacijos (darbo pokyčių)“ sritį sudarè šeši teiginiai, susiję su bendradarbiavimu atliekant pokyčius, jų viešu aptarimu, prasmingumu, saugumo pojūčiu, darbuotojų poreikių ir norų atitikimu bei informavimu apie reorganizaciją. Šios srities teiginiai buvo vertinami blogiau nei kitų sričių. Vidurkis bendroje tiriamujų grupèje - 3,29-3,64 balo (2 lentelè).

\section{2 lentelè. Darbo patirties sričių palyginimas tarpusavyje}

\begin{tabular}{|l|l|l|l|l|l|l|l|}
\hline \multicolumn{1}{|c|}{$\begin{array}{c}\text { Pokyčiai } \\
\text { darbe }\end{array}$} & $\begin{array}{c}\text { Ver- } \\
\text { tini- } \\
\text { mas } \\
\text { ba- } \\
\text { lais }\end{array}$ & $\begin{array}{c}\text { Palaikan- } \\
\text { tys darbo } \\
\text { santykiai }\end{array}$ & $\begin{array}{c}\text { Verti- } \\
\text { nimas } \\
\text { balais }\end{array}$ & $\begin{array}{c}\text { Individuali } \\
\text { patirtis }\end{array}$ & $\begin{array}{l}\text { Verti- } \\
\text { nimas } \\
\text { balais }\end{array}$ & $\begin{array}{c}\text { Vadova- } \\
\text { vimas }\end{array}$ & $\begin{array}{l}\text { Verti- } \\
\text { nimas } \\
\text { balais }\end{array}$ \\
\hline $\begin{array}{l}\text { Informuotu- } \\
\text { mas }\end{array}$ & 3,29 & $\begin{array}{l}\text { Paskatini- } \\
\text { mas }\end{array}$ & 4,97 & $\begin{array}{l}\text { Prasmingu- } \\
\text { mas }\end{array}$ & 5,14 & $\begin{array}{l}\text { Tarima- } \\
\text { sis }\end{array}$ & 4,23 \\
\hline Atitikimas & 3,31 & Pagalba & 4,97 & $\begin{array}{l}\text { Užduočių } \\
\text { ivertinimas }\end{array}$ & 4,88 & $\begin{array}{l}\text { Sudomi- } \\
\text { nimas }\end{array}$ & 4,33 \\
\hline Saugumas & 3,56 & Atmosfera & 4,77 & $\begin{array}{l}\text { Tobulèji- } \\
\text { mas }\end{array}$ & 4,81 & $\begin{array}{l}\text { Paskirs- } \\
\text { tymas }\end{array}$ & 4,40 \\
\hline $\begin{array}{l}\text { Prasmingu- } \\
\text { mas }\end{array}$ & 3,57 & Rutina & 4,70 & $\begin{array}{l}\text { Išsilavini- } \\
\text { mo atitiktis }\end{array}$ & 4,60 & $\begin{array}{l}\text { Informa- } \\
\text { cija }\end{array}$ & 4,42 \\
\hline Aptarimas & 3,61 & Savijauta & 4,47 & Malonumas & 4,60 & $\begin{array}{l}\text { Prièmi- } \\
\text { mas }\end{array}$ & 4,65 \\
\hline $\begin{array}{l}\text { Bendradar- } \\
\text { biavimas }\end{array}$ & 3,64 & Ivertinimas & 5,35 & Iššūkis & 3,81 & $\begin{array}{l}\text { Pasiekia- } \\
\text { mumas }\end{array}$ & 4,82 \\
\hline
\end{tabular}

Vertinant darbo patyrimo sritis pagal tiriamujjų lytị, nustatytas statistiškai reikšmingas srities, susijusios su reorganizacija, vertinimų skirtumas - vyrai žymiai pozityviau vertino savo patyrimą, susijusị su pokyčiais įstaigoje, nei moterys. Analizuojant darbo laiko panaudojimo sričių vertinimus, priklausomai nuo amžiaus, nustatyta, kad vadovavimo ir reorganizacijos sričių vertinimai susiję su tiriamujų amžiumi $(\mathrm{p}<0,05)$. Vadovavimo sriț pozityviau vertino vyresnio amžiaus tiriamieji nei jaunesnio, ypač palyginus su jauniausio amžiaus (iki 30 metų) grupe (48,46 balo).

Darbo patyrimo sričių vertinimų vidurkių lyginimo rezultatai, atsižvelgiant tiriamujų darbo krūvị, parodè, kad tiriamuju atsakymai statistiškai reikšmingai skyrèsi palaikančių darbo santykių srityje $(p=0,003)$, dirbantieji mažesniu bendru krūviu palaikančius darbo santykius vertino pozityviau nei dirbantieji didesniu krūviu $(>0,5-1$ etato grupèje $-72,61 \pm 15,05$ balo ir daugiau nei vieno etato grupejje 
$65,40 \pm 19,76$ balo, $\mathrm{p}=0,037)$ ir vadovavimą $(>0,5-1$ etato grupeje 73,51 balo ir daugiau nei vieno etato grupeje 62,97 balo, $p=0,033$ ).

Tyrimo rezultatai parodè, kad geresnè sveikata, ivertinta salutogeniniais indikatoriais, yra susijusi su geresniais darbo santykiais, laiko paskirstymu, vadovavimu ir pozityvesniu požiūriu ị reorganizaciją.

\section{REZULTATŲ APTARIMAS}

Atlikus Vakarų Lietuvos ligoninėse dirbančių slaugytojų sveikatos, ịvertintos salutogeniniais indikatoriais, priklausomai nuo darbo veiksnių, tyrimą, nustatyta, kad geresnè slaugytojų sveikata statistiškai reikšmingai susijusi su geresniais darbo santykiais, laiko patyrimu, geresniu vadovavimu ir pozityvesniu požiūriu ị reorganizaciją. Taigi, tyrimo rezultatų duomenimis, geresnè sveikata, ịvertinta salutogeniniais indikatoriais, yra susijusi su geresniais darbo santykiais, tai savo tyrime patvirtino J. Andriuškienė et al. (2016). P. Nilsson et al. (2010) pabréžia, kad darbo patirtis yra reikšminga darbuotojo sveikatai, todèl teigiamos darbo patirties turèjimas gali būti laikomas darbuotojo sveikatos šaltiniu. S. S. Persson et al. (2018) tyrimas patvirtino, kad slaugytojų pozityvių santykių stiprinimas darbo vietoje su vadovais bei slaugos paslaugu gavëjais yra pagrindinis veiksnys, kuris prisideda prie slaugytojų sveikatos stiprinimo. Mūsų tyrimo duomenimis, išanalizavus slaugytojų darbo patirties vertinimą, geriausiai slaugytojai vertino savo darbo prasmingumą, bendradarbių pagalbą ir palaikymą. C. Bergman et al. (2017) teigia, kad glaudus bendradarbiavimas darbe siejasi su bendru komandos klimatu, o tai turi įtakos ne tik pacientų priežiūros kokybès rezultatams, bet ir sveikatą stiprinančios darbo aplinkos palaikymui. Taigi, tiek analogiškų tyrimų R. Burke, L. Fiksenbaum (2009), tiek mūsų tyrimo rezultatai rodo, kad sveikatos priežiūros specialistai, kurie palankiau vertina savo sveikatą, pozityviau vertina ir darbo patirti.

Analizuojant sveikatos rodiklius, priklausomai nuo tiriamųų lyties, amžiaus, statistiškai reikšmingų skirtumų nenustatyta, tačiau vertinimai yra susiję su slaugytojų darbo stažu - didesnę nei 16 metų darbo patirtị turintys slaugytojai statistiškai reikšmingai blogiau vertino ir tarpasmeninius, ir interaktyvius sveikatos indikatorius nei turintieji mažesnị darbo stažą. Tą nurodo savo darbe ir J. Andriuškienè et al. (2016). Slaugytojai, išdirbę 6-10 metų, palankiau nei daugiau nei 20 metų išdirbusieji vertino savo patyrimą, susijusị su pokyčiais ịstaigoje. Reorganizaciją prasčiausiai vertino vyresniujų slaugytojų grupè. Vadovavimo sritị pozityviau vertino vyresnio amžiaus slaugytojai nei jaunesnio, ypač palyginus su jauniausia (iki 30 metu) grupe. P. Nilsson et al. (2013) nuomone, svarbu analizuoti darbo vertinimą, 
susijusị su amžiumi, pasidalijimu žiniomis, bendradarbiavimu, siekiant išsiaiškinti, kokie motyvacinio darbo veiksniai yra reikšmingi skirtingoms amžiaus grupėms. E. Piekutė et al. (2016) nustatė, kad darbuotojai, dirbantys mažesniu krūviu, palaikančius darbo santykius vertina palankiau. M. A. Ibrahim et al. (2019) tyrimo duomenimis, kuo daugiau laiko darbuotojai praleidžia ịstaigoje, tuo jų lūkesčiai tampa realistiškesni, o nuolatinis bendravimas su kolegomis gerina jų santykius, mažèja darbuotojų stresas, išvengiama depresijos arba perdegimo sindromo.

\section{IŠVADOS}

1. Nustatytas statistiškai reikšmingas ryšys tarp tiriamujų darbo stažo ir bendrojo sveikatos rodiklio. Tiriamujų, turinčių didesnį nei 16 metų darbo stažą, rodiklis, palyginus su nedidelį darbo stažą turinčiais tiriamaisiais, buvo žymiai blogesnis, blogiau vertinami tiek tarpasmeniniai, tiek interaktyvūs sveikatos indikatoriai.

2. Nustatytos slaugytojų sveikatos sąsajos su darbo patirties psichosocialiniais veiksniais - teigiama darbo patirtis buvo susijusi su geresniu savo sveikatos ir savijautos vertinimu.

3. Mūsų tyrimo rezultatų duomenimis, geriausiai slaugytojai įvertino bendradarbių pagalbą ir palaikymą, savo darbo prasmingumą, galimybę tobulèti ir spręsti, kaip darbas turi būti atliekamas, prieinamumą prie vadovo, vadovo konsultavimąsi su darbo grupe prieš priimant svarbius sprendimus, o blogiausiai vertino darbdavio rūpinimąsi darbuotojų sveikata, informavimą apie reorganizaciją bei jos atitiktị darbuotojų poreikiams ir norams.

\section{LITERATŪRA}

Andruškienė, J., Kuzmienè, A., Martinkėnas, A., et al. (2016). Psychosocial Work Experiences Related to Health: A Study of Lithuanian Hospital Emplyees. Work, 53 (3), 669-677.

Bergman, C., Löve, J., Hultberg, A., Skagert, K. (2017). Employees' Conceptions of Coworkership in Swedish Health Care Organization. Nordic Journal of Working Life Studies, 7 (4), 91-107.

Bringsén, Å., Andersson, H.I., Ejlertsson, G. (2009). Development and quality analysis of the Salutogenic Health Indicator Scale (SHIS). Scandinavian Journal of Public Health, 37, 13-20.

Bratikaitè, L. (2010). Profesinio „perdegimo“ sindromas tarp slaugytojų, dirbančių su onkologiniais pacientais: paplitimas, priežastys, simptomai, prevencija. Slauga. Mokslas ir praktika, 7 (8), 4-10.

Burke, R., Fiksenbaum, L. (2009). Virtues, work satisfactions and psychological wellbeing among nurses. International Journal of Workplace Health Management, 2, 202-219.

Dringelytė, K., Gulbinienė, J. (2019). Slaugytojų miego ir gyvenimo kokybės sąsajos. Sveikatos mokslai, 6 (29), 195-200.

Ibrahim, M. A., Aziz, A. A., Suhaili, N., et.al. (2019). A Study into Psychosocial Work Stressors and Health Care productivity. Int J Occuo Environ Med, 10, 185-193.

Martinaitytė, M. 2018. Profesinio perdegimo sindromo problematika skubios pagalbos slaugytojų darbe: kodėl ir kaip? Verslas, technologijos, biomedicina: inovaciju jžzalgos: respublikine moksline - praktiné studenty konferencija: straipsniu rinkinys, 1 (9), 290-296. 
Karpavičiūtè, S. (2016). Slaugytoju subjektyvi sveikata, patiriamas stresas, nuovargis ir dalyvavimo meninejje veikloje poveikis: daktaro disertacija. Kaunas.

Nilsson, P., Andersson, I. H., Ejlertsson, G., Troein, M. (2012). Workplace health resources based on sense of coherence theory. Int Journal Workplace Health Manag, 5 (3), 156-167.

Polikandrioti, M. (2009). Editorial article: Burnout sindrome. Health Science Journal, 3, 195-196.

Persson, S. S., Lindström, P. N., Pettersson, P. \& Andersson, I. (2018). Workplace relationships impact self-rated health: A survey of Swedish municipal health care employees. Work, 60 (1), 85-94.

Piekute, E., Andruškienè, J., Martinkènas, A., et al. (2016). Assumptions of Workplace Health Promotion in Primary Health Care. Professional Studies: Theory and Practice, 2 (17), 42-48

Vimantaite, R. (2005). Išsekimo sindromas. Lietuvos bendrosios praktikos gydytojas, 2 (9), 120-122.

Žiedelis, A. (2019). Slaugytojų psichosocialinių darbo aplinkos veiksnių sąsajos su ịsitraukimu ị darbą ir perdegimu. Psichologija, 59, 53-67.

\title{
THE IMPACT OF WORKING ENVIRONMENT FACTORS ON HEALTH OF NURSES
}

\author{
Gintarẻ Aukštikalnytė, Danguolė Drungilienė, \\ Viljaras Reigas, Gintautas Minelga \\ Klaipeda University
}

\begin{abstract}
Background. Work environment of health care professionals is a very important factor having an impact on their health and quality of life. Health care professionals' experiences psychosocial risk factors such as stress, long working hours, high requirements, patient violence and deaths, working in shifts, etc. Work-rest regime disbalance cause stress in employees, burnout, and deterioration of health. Not all nurses are able to deal with permanent pressure and stress at work therefore the possibility of unwanted health problems arise.
\end{abstract}

The aim. To analyze the impact of work environment factors on health of nurses.

Methods. 121 nurses were surveyed in hospitals. The prepared research instruments were used: working experience measurement scale (WEMS) and salutogenic health indicator scale (SHIS).

Results. Health of nurses were evaluated by "Salutogenic health indicator scale". The total health indicator average in a general research participant group was 60.96 points, interpersonal health indicators in groups equaled 59.81 points, and interactive -62.58 points. Communication with other people (4.38 points), determination (4.27 points), maintaining emotional balance (4.20 points) were best rated; the worst results were for sleep (3.74 points), relaxation (3.82 points) and energy ( 3.85 points). The working experience scale showed best results of acces- 
sibility towards manager, manager's ability to make decisions in need; the worst results were of a manager consultation with a working group before making important decisions.

Conclusion. It is stated that work experience showed a connection with better evaluation of health and wellbeing. The total health indicator was significantly worse for the participants with a longer work experience thus they evaluated interpersonal and interactive health indicators worse in comparison to other participants. Younger nurses evaluated changes in an organization more positively, however management area was evaluated more positively by nurses with longer work experience.

Keywords: nurses, health indicators, work factors

Pateikta: 2021-02-04

Priimta: 2021-03-29 